\title{
A gripe espanhola na Bahia: saúde, política e medicina em tempos de epidemia
}

\author{
Spanish flu in Bahia: health, politics and \\ medicine in times of epidemics
}

\author{
Christiane Maria Cruz de Souza \\ Tese de doutoramento em História das Ciências, Casa de Oswaldo Cruz/Fundação Oswaldo Cruz. \\ Rio de Janeiro, 2007 \\ christianecruz@hotmail.com
}

A tese intitulada A gripe espanhola na Bahia: saúde, política e medicina em tempos de epidemia versa sobre a epidemia de gripe que irrompeu em Salvador, em meados de setembro de 1918, e dali, seguindo os caminhos dos trens, dos rios e do mar, adentrou o estado, em percurso que durou até os primeiros meses de 1919. Escolhemos tal objeto de estudo no intuito de deslindar a trama do tecido histórico que constituía a sociedade baiana nos primeiros decênios do século XX. Com esse trabalho buscamos analisar como a doença se infiltra na vida das pessoas, as reações que provoca e a maneira pela qual dá expressão a valores sociais, culturais e políticos. Para tanto, usamos como campo privilegiado de reflexão a cidade do Salvador, tendo em vista não só a sua condição de capital, mas também o fato de ser o pólo político, socioeconômico e cultural do estado e da região Norte do país, sem mencionar sua tradição nos estudos da medicina. Contudo, fugindo um pouco dos relatos da experiência da epidemia nos grandes centros urbanos, consideramos também importante analisar a emergência do surto epidêmico no interior do estado e, assim, revelar as múltiplas faces da Bahia. Pretendemos demonstrar que, ao incidir sobre a Bahia, a epidemia de gripe espanhola provocou os transtornos característicos da erupção de um surto epidêmico - mortes, isolamento, vigilância domiciliária e portuária, paralisação de fábricas e serviços -, mobilizando, para o seu controle, diversos setores da sociedade. O impacto do surto epidêmico colocou em evidência as fragilidades da sociedade baiana na República Velha: o clientelismo e o nepotismo que corrompiam a máquina estatal; o facciosismo político e os conflitos daí decorrentes; a ausência de políticas públicas de saúde abrangentes, contínuas e eficazes; a relação entre as questões econômicas e a condição sanitária da capital do estado; as práticas institucionais e a legislação que as presidia, e as precárias condições de vida e saúde do povo baiano. Apesar de todas as dificuldades enfrentadas, o povo baiano não se deixou abater pelo sofrimento advindo da fragilidade física conseqüente à doença, nem pela intensificação das experiências de morte. Mesmo em condições adversas, usou todos os meios de que dispunha para vencer a 'espanhola'.

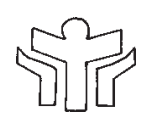

